\title{
Study Literature Review On Returning Medical Record Documents Using HOT-FIT Method
}

\author{
Deni Maisa Putra ${ }^{1 *}$, Oktamianiza ${ }^{1}$, Mega Yuniar ${ }^{1}$, Washi Fadhila ${ }^{2}$ \\ ${ }^{1}$ Department of Medical Record and Health Information Study Program, STIKES Dharma Landbouw, Padang, Indonesia \\ ${ }^{2}$ Medical Record and Health Information Practitioner, RSUP Dr. M. Djamil Padang, Indonesia \\ *Corresponding author E-mail: denimaisaputra@gmail.com
}

Manuscript received 1 Jan 2021; revised 10 Jan 2021; accepted 15 Jan 2021. Date of publication 20 Jan 2021

\begin{abstract}
The return of medical record files is a system that is quite important in medical records, because the return of medical records starts from the file in the inpatient room until it returns to the medical record section in accordance with the return policy, which is $2 \times 24$ hours. The method used is a literature study with descriptive analysis which is done by describing the facts that exist then being analyzed, described, looking for similarities, views, and summaries of several studies. The results of the literature study show that humans are not responsible for returning medical record files, the organization lacks supervision from the management of returning files, technology (technology) with technology can assist in returning medical record files. So it is necessary to pay attention to the 3 components, so that it can produce a benefit (Net Benefit) from returning the medical record document. Based on the results of the study, it can be concluded that the factors that influence the return of medical record documents are in terms of the HOT-FIT method, (human) where the officers lack a sense of responsibility for medical record documents, and doctors and nurses do not pay attention to the form of filling out record documents medical records, so that it becomes an obstacle in returning medical record documents. It's good to have good supervision from the management.
\end{abstract}

\section{Keywords: Document Return, Medical Record, HOT-FIT.}

\section{Introduction}

The quality of health services in hospitals is data or information from good and complete medical records. Indicators of good medical record quality are completeness of content, accuracy, timeliness and fulfillment of legal requirements. Therefore, in managing medical records, every hospital always refers to the guidelines or technical instructions for managing medical records made by the hospital concerned. Management of medical records in hospitals is to support the achievement of orderly administration in an effort to achieve hospital goals, namely improving the quality of health services in hospitals. In managing medical records to support the quality of services for hospitals, medical record management must be effective and efficient [1].

A complete medical record is a medical record that has been completely filled out by a doctor in less than 24 hours after completing outpatient services or after an inpatient has decided to go home. The return of medical record documents is declared late if it exceeds the return time limit. Maximum 2x24 hours after the patient is discharged from the hospital. This delay will hinder the implementation of the duties of the medical record assembling section which can have an impact on delaying patient services due to the return of medical records. The return of medical record files often experiences delays from the ward to the medical record unit, thus affecting the medical record processing process, medical records must be filled out in the ward or in the treatment room by health practitioners, such as doctors, nurses, midwives, and others after the patient returns home the record file must be filled out and completed by the doctor who is responsible for patient care. The medical record file of the discharged patient that has been filled in by the doctor must be immediately returned to the medical record unit no later than 2 x 24 hours. The admissions officer checks the completeness of the medical record file and writes on the expedition book to receive the medical record file from the room [2].

Problems that are often found in retrieval of medical record documents (Retrieval) are not found on the medical record document storage rack, thus making officers overwhelmed in finding medical record documents when medical records are needed. This is due to errors in the alignment of medical records on storage shelves, medical records borrowed by doctors, and medical records that are still in the polyclinic, medical records that are not found will result in delays and increase service time for patients. So that the service to the patient becomes inefficient. The delay in returning medical record files will hinder further activities, namely coding, indexing, and possibly causing loss or damage to medical record files. If this happens on an ongoing basis it will hinder the delivery of information to hospital leadership for decision making. Besides that, it can also hamper the next service activity if at any time it is needed for legal purposes [3]. 
The return of medical record files is a system that is quite important in the medical record section, because the return of medical records starts from the file in the inpatient room until it returns to the medical record section in accordance with the return policy, which is $2 \times 24$ hours. The policy of returning medical record files is very important and more effective by using information technology [4].

Electronic Health Record (RKE) is an activity to computerize the contents of health medical records and the associated electronicization process. This electronics produces a system that is specifically designed to support users with various facilities for completeness and accuracy of data, giving alerts, warnings, signs of clinical decision support systems and connecting data with medical knowledge and other tools. A computerized medical record system can reduce human errors in doing their work and can improve the quality of services provided to each patient who is treated. Therefore, the use of a computerized-based information system in a hospital is very important in carrying out service activities for patients [5].

Based on the description above, the researchers are interested in conducting a "Literature Study On the Return of Medical Record Documents With the HOT-FIT Method".

\section{Literature Review}

\subsection{Medical Record}

Medical record is a file containing records and documents regarding patient identity, examination, treatment, actions and other services that have been provided to patients. Notes are writings made by doctors or dentists about all actions taken to patients in the context of providing health services. Documents are records of doctors, dentists, and or certain health workers, reports on the results of supporting examinations, daily observation and treatment records and all recordings, both in the form of radiology photos, imaging images, and electro-diagnostic recordings [6].

\subsection{Medical Record Purpose}

The purpose of medical records is to support the achievement of orderly administration in the context of efforts to improve health services in hospitals. Without the support of a good and correct medical record processing system, an orderly hospital administration will not be achieved as expected. Meanwhile, administrative order is one of the determining factors in the efforts of health services in hospitals [2].

\subsection{Medical Record File Retrieval}

Requests for borrowing medical records that are not routine, such as for emergency unit assistance, inpatient units must be fulfilled as soon as possible. Telephone requests can also be served and other parts requesting. Officers from other departments who request, must come in person to take the requested medical records to the unit/medical record section. The request letter is usually in the form of a form containing the patient's name and medical record number, the name of the clinic or the name of the part/person who borrows, the date of borrowing the medical record, and the due date for returning the medical record [2].

\subsection{Storage System}

Judging from the centralization or unification of medical record documents, the storage method is divided into 2, namely:

a. Centralized Storage System

A centralized medical record document storage system is a storage system by uniting a patient's medical record form into a single unit (folder). Outpatient, inpatient, and emergency medical record documents belonging to a patient become one in a unified folder (map).

b. Decentralized Storage System

A decentralized medical record document storage system is a storage system by separating the property of a patient between outpatient, inpatient, and emergency medical record documents in separate folders and/or separate places. Usually, the patient's medical record documents, outpatient medical records are stored in one storage area or in their respective polyclinics, while the emergency and inpatient medical records are stored in the medical records section.

\subsubsection{Medical Record Document Alignment System}

Medical record documents stored in storage racks are not stacked but arranged to stand parallel to one another. The order of alignment of the medical record documents follows the order of the medical record number in three ways, namely:

a. Straight Numerical Filing Alignment System (SNF)

Alignment system with direct number is a medical record document storage system by aligning the medical record document folder based on the direct order of the medical record number on the storage rack. For example, the following four medical records will be stored sequentially in one shelf. Namely 46-50-23, 46-50-24, 46-50-25, 46-50-26.

b. Digit Filing Terminal Alignment System (TDF)

The Terminal Digit Filing alignment system is a medical record document storage system by aligning the medical record document folder based on the sequence of medical record numbers in the final 2 digits of the group.

c. Middle Digit Filing Alignment System (MDF)

Alignment system with the middle number system or MDF is a medical record document storage system by aligning the medical record document folder based on the sequence of medical record numbers in the 2 middle group digits. 


\subsubsection{Human Organization Technology (HOT) Model Fit}

The HOT Fit model framework is the development of the Delone and Melean SI success model, namely adding organizational factors and their dimensions, structure and environment, fit between technological, human and organizational factors, two ways of relationship between the dimensions of information quality and system use, information quality and user satisfaction, structure and environment, structure and net benefit, and environment and net benefit [7].

Human Organization Technology (HOT) Fit is one of the theoretical frameworks used to evaluate information systems in the health care sector. This evaluation method clarifies all the components contained in the information system itself, the first is humans (humans) who assess information systems in terms of use (system use) related to who uses, training, experience, knowledge, expectations, and acceptance. or reject the system. The second is the organization which assesses a system from the organizational structure and organizational environment related to planning, management, system control, management support, and financing and the third is technology (technology) which assesses in terms of system quality, information quality and service quality [4].

\section{Methods}

This type of research is descriptive qualitative, that is, research that aims to get a picture that is analyzed by the literature review method. The object of this research is the medical record document. Data collection is carried out using secondary data which is supporting data sourced from various literatures and existing references. Data analysis was also carried out using literature review techniques including looking for similarities (compare), looking for dissimilarities (contrast), giving views (critize), compare (synthesize), and summarize (summarize).

\section{Results and Discussion}

The results obtained based on the study of literature can be described as follows:

1. Human Component

From the results of research conducted by [8] regarding delays in returning medical record files due to incomplete filling of medical record files by doctors. From the aspect of monitoring and evaluating medical record files, medical record officers do not monitor and evaluate medical record files for inpatients due to a shortage of personnel at the medical record installation. Meanwhile, from the aspect of doctor compliance, there are more doctors who do not comply in filling out and completing the patient's medical record file.

While the results of research conducted by [9] concerning There is a significant relationship between the absence of monitoring and supervision in returning medical record files. Therefore, the human component plays an important role in returning medical record documents. Because humans are more responsible for medical record documents

2. Organization component

Based on the results of research conducted by[10] regarding the results of research, supervision and control of the implementation of medical record files in hospital $\mathrm{X}$ does not yet exist and the lack of effective communication of the medical record unit, both internal and external.

From the results of research conducted by [7] about the delay in returning inpatient DRM to the medical record section is a problem that arose in Hospital X, especially after Hospital X collaborated with BPJS. Therefore, the organization really needs to pay attention so that no mistakes arise from both internal and external parties.

3. Technology components

From the results of research conducted by [3] regarding the results of this study, it is asked that technology plays an important role in medical records. Therefore, technology also plays an important role in returning medical record documents. Technology is also a supporting tool in returning medical record documents, so it can save time.

In conducting a journal review, it can be done using literature review techniques, including determining the similarity (compare), determining the dissimilarity (contrast), giving a view (critize), compare (synthesize), and summarize (summarize).

1. Similarity (compare)

From several journals that have been analyzed, there are fundamental similarities to the return of medical record documents with the Hot Fit method. But in this similarity, the researcher examines in terms of the Hot Fit method. Which is where human (human) as one of the important components in an information system.

In the journal [11] states that the human component is the provider and user of the information system. It is an important part of the information system. Meanwhile, the journal [13] states that the human component (human) assesses information systems in terms of system use (system use) on the frequency and breadth of information system functions and investigations.

2. Inequality (contrast)

Some of these journals also found dissimilarities in the return of medical record documents. In the journal [7] it is known that the factors that cause delays in returning inpatient medical record documents to the medical records section 
at Hospital X are very complex. The most dominant factor is the human resource factor which consists of the lack of discipline of doctors in filling out medical records, especially medical resumes.

From the journal [4] it is known that the factor of delay in returning medical record documents is due to delays in making medical resumes by DPJP and the absence of monitoring and supervision related to delays in returning medical record files.

3. View (criticize)

From the analysis and analysis of several journals, it can be seen that the return of medical record documents to the medical record unit has not met the established standards. This is seen from a human perspective because there is still a lack of responsibility from internal and external parties for returning the medical record files. From an organizational perspective, it is a stable formal structure and takes resources from the environment and processes them to create outputs. In terms of technology (technology), the technology component that assesses the information system consists of system quality (system quality), information quality (information quality). From the benefits (net benefit) is a balance between the positive and negative impacts of users of information systems.

4. Compare (synthesize)

According to [2] the return of medical record files is often delayed from the ward to the medical record unit, thus affecting the medical record processing process, medical records must be filled out in the ward or in the treatment room by health practitioners, such as doctors, nurses, midwives, and others. -Other after the patient goes home the medical record file must be filled out and completed by the doctor who is responsible for patient care. The medical record file of the discharged patient that has been filled in by the doctor must be immediately returned to the medical record unit no later than $2 \times 24$ hours. The reception officer checks the completeness of the medical record file and writes on the expedition book to receive the medical record file from the room.

Where the comparison results can be seen from research conducted by [7] assembling officers assess the completeness of the returned DRM, if it is considered incomplete then the DRM will be returned to the inpatient room to be completed within 2 × 24 hours.

While in research [14] that the accuracy of returning inpatient medical records on time ( $\geq 2 \times 24$ hours) is $44 \%$ and the return of medical records that are not on time ( $<2 \times 24$ hours $) 55.6 \%$.

\section{Summary (Summarize)}

a. Human Component (Human)

The human component assesses information systems in terms of system use on the frequency and breadth of information system functions and investigations. System use also relates to who uses it (who uses it), the level of use (level of user), training, knowledge, expectations and attitudes to accept or reject the system. This component also assesses the system from the aspect of user satisfaction, namely the overall evaluation of the user's experience in using the information system and the perceived potential impact of using the information system. User satisfaction can be related to the perceived benefits and attitudes of users and information systems that are influenced by personal characteristics [15].

From several studies, it was found similarities regarding human factors that affect the electronic retrieval of medical records because the falling officers did not pay attention to the SOPs that had been set at the hospital and the officers lacked knowledge of the electronic retrieval. The hospital should monitor the falling section and provide socialization to the medical record officer in the falling section. In order to create an accurate electronic retrieval of medical records.

b. Organizational Components

The Organizational Component assesses the system from the aspect of the organizational structure and organizational environment where the information technology system is implemented. While the organizational environment consists of sources of financing, government, politics, competition, interorganizational relations and communication [15].

From several studies found similarities regarding organizational factors that affect the electronic retrieval of medical records due to the lack of supervision from internal parties so that there is a delay in returning medical record files. As with the medical record file that was borrowed by the BPJS due to the lack of supervision, there was a delay in returning the medical record file. The hospital, especially the internal party from the medical record, should further improve supervision of the return of medical record files.

c. Component Technology (Technology)

The technology component consists of system quality, information quality and service quality. The quality of the system in the information system in health care institutions concerns the interrelation of features in the system including system performance and user interface. Ease of use (ease of use), ease of learning (ease of learning), response time, usefulness, availability, flexibility, and security are variables or factors that can be assessed from the quality of the system. The criteria that can be used to assess the quality of information include completeness, accuracy, timeliness, availability, relevance, consistency, and data entry. Meanwhile, service quality focuses on the overall support received by the system or technology service provider. Service quality can be assessed by the 
speed of response, assurance, empathy and follow-up services. Therefore, in the third component of technology (technology) indicators are set with assessment indicators including system quality (system quality), quality (information quality) and service quality (Ridwan, 2019).

From the results of the research analysis, it is stated that technology plays an important role in medical records. Because it will help officers in their work and efficiency with time, will also have an impact on patient service time. Therefore, hospitals can pay more attention to the need for technology in medical records.

\section{d. Net Benefit Component}

Net benefits can be measured from the benefits of the system directly or from indirect benefits such as the impact on performance, efficiency, and effectiveness of organizational activities [7].

All of the above components can produce something that is beneficial for both internal and external parties. Therefore the need for humans (humans), organizations (organizations) technology (technology) so that they can produce something useful for electronic retrieval of medical records.

\section{Conclusions}

The human component, the lack of a sense of responsibility for returning medical record documents, and the lack of personnel who have high expertise and commitment. in the organizational component, there are still some organizations that are not appropriate, such as no support and development from the management, and no supervision, no evaluation and SOP in the application of electronic retrieval in medical records

There are technological components that have a quality system that is easy to use and is still not running optimally because of the poor internet network, and there is still a shortage of computers for related parties. For the electronic retrieval benefit component, it is very important, and has a very positive impact and helps in work such as easier, faster, and no delays in returning medical record files.

To improve the expertise of human resources managing the return of medical record documents, training or socialization for medical record officers is held. In the organizational aspect, more attention is paid to supporting infrastructure and supervision because without the support of management, many problems will arise that can affect the application of electronic medical record retrieval. Electronic retrieval evaluation should be carried out in order to find out in meeting user needs. Shared understanding and commitment about the benefits of electronic retrieval for all users and paying attention to the factors that encourage or hinder electronic retrieval for its future development.

\section{References}

[1] A. Pengelolaan et al., "Analisis Pengelolaan Rekam Medis Di Rumah Sakit Umum Pancaran Kasih Manado,” Kesmas, vol. 7, no. 4, 2018.

[2] DepKes RI, Pedoman Prosedur Dan Penyelenggaraan Rekam Medis di Rumah Sakit Di Indonesia. DepKes RI Dirjen Bina Pelayanan Medik: Jakarta. 2006.

[3] D. M. Putra, “Tinjauan Pelaksanaan Kerahasiaan Rekam Medis Di Puskesmas Kuranji Padang,” vol. 6, no. 1, pp. 58-66, 2021.

[4] Deni Maisa Putra \& Dila Vadriasmi, "Analisis Penerapan Sistem Informasi Manajemen Rumah Sakit (SIMRS) Di TPPRJ Menggunakan Metode UTAUT DI RS TK.III DR. Reksodiwiryo Padang,” vol. 1, no. 1, pp. 10-18, 2020.

[5] D. M. Putra, D. Z. Yasli, D. Leonard, and Y. Yulia, "Penerapan Sistem Informasi Manajemen Puskesmas (SIM-PUS) PAda Unit Rekam Medis Dan Informasi Kesehatan Di Puskesmas Lubuk Buaya Kota Padang," no. August 2019, pp. 67-72, 2020.

[6] Menkes RI, "Peraturan Menkes RI No.269/Menkes/III/2008 Tentang Rekam Medis atau Medical Record, Jakarta,” 2008.

[7] T. Wulandari, "Study Literature Review Tentang Implementasi Simrs Pada Unit Kerja Rekam Medis Rawat Jalan Dengan Metode Hot-Hit," Adm. Heal. ..., vol. 1, no. 2, pp. 157-170, 2020, [Online]. Available: http://ojs.stikeslandbouw.ac.id/index.php/ahi/article/view/167.

[8] L. M. Y. Janwarin, N. Makmun, S. Titaley, H. J. Huliselan, and F. The, “Analisis Keterlambatan Pengembalian Berkas Rekam Medis di Rumah Sakit," Mollucas Heal. J., vol. 1, pp. 30-36, 2019.

[9] M. Husni and D. M. Putra, "Analisis Implementasi Sistem Informasi Manajemen Rumah Sakit (SIMRS) Pada Unit Kerja Rekam Medis Di Rsu'aisyiah Padang,” J. Kesehat. Lentera 'Aisyiyah, vol. 2, no. 1, pp. 19-26, 2019.

[10] Oktamianiza, "Ketepatan Pengodean Diagnosis Utama Penyakit pada Rekam Medis Pasien Rawat Inap JKN (Jaminan Kesehatan Nasional) di RSI Siti Rahmah Padang Tahun 2016," Penelit. dan Kaji. Menara Ilmu, 2016.

[11] Oktamianiza, "Analisis Penerapan Kode Morfologi Pada Diagnosa Neoplasma Rekam MEDIS RAWAT INAP DI RSI Siti Rahmah Padang,” vol. 1, no. 1, pp. 55-67, 2020.

[12] D. Makalalag, F. Agushybana, and A. Mawarni, "Evaluasi Sistem Informasi Pelayanan Rekam Medis di RSJ Prof. Dr. V.L. Ratumbuysang Provinsi Sulawesi Utara dengan Pendekatan Hot Fit Model,” J. Manaj. Kesehat. Indones., vol. 5, no. 2, pp. 82-93, 2017, doi: 10.14710/jmki.5.2.2017.82-93.

[13] A. D. Putra, "Evaluasi Sistem Informasi manajemen Rumah Sakit (SIMRS) Dengan Metode Hot Fit Di Rsud Andi Makkasau Kota Parepare," J. Ilm. Mns. dan Kesehat., vol. 1, no. 1, pp. 61-68, 2020, [Online]. Available: http://umpar.ac.id/jurnal/index.php/makes/article/view/294.

[14] O. D. Elvira, D. M. Putra, W. Sumatra, W. Sumatra, and B. R. Medis, "Study Literature Review Tentang Pendistribusian Berkas Rekam Medis Rawat Jalan," vol. 2, no. 1, pp. 161-170, 2021.

[15] S. Erimalata, "Pendekatan Hot-Fit Framework dalam Generalized Structural Component Analysis pada Sistem Informasi Manajemen Barang Milik Daerah: Sebuah Pengujian Efek Resiprokal,” J. Akunt. dan Investasi, vol. 17, no. 2, pp. 141-157, 2016, doi: 10.18196/jai.2016.0051.141-157. 